\title{
FIBRINOLYSIS, ANTITHROMBIN III, AND PROTEIN C IN NEONATES DURING CARDIAC OPERATIONS
}

Jari Petäjä, MDa

Kaija Peltola, $\mathrm{MD}^{\mathrm{a}}$

Heikki Sairanen, $\mathrm{MD}^{\mathrm{a}}$

Mauri Leijala, $\mathrm{MD}^{\mathrm{a}}$

Riitta Kekomäki, $\mathrm{MD}^{\mathrm{b}}$

Elina Vahtera, Phil Lic ${ }^{\mathrm{b}}$

Martti A. Siimes, MD $^{\mathrm{a}}$
Fibrinolysis and coagulation were studied in 10 neonates undergoing cardiac operations for congenital heart defects. Coagulation was activated during cardiopulmonary bypass as evidenced by highly increased prothrombin fragment $1+2$ levels compared with preoperative values. Prothrombin fragment 1+2 levels remained elevated until postoperative day 3 . Unlike coagulation, fibrinolysis was not activated during cardiopulmonary bypass but did show late activation on postoperative day 3 , as evidenced by elevated levels of the fibrin degradation product D-dimer. Lack of fibrinolytic activation during bypass and its appearance on postoperative day 3 were partly explained by changes observed in tissue plasminogen activator and its inhibitor. During bypass, levels of tissue plasminogen activator and its inhibitor increased by 3.4-fold and 3.2-fold, respectively. In the postoperative period, levels of plasminogen activator inhibitor normalized rapidly whereas tissue plasminogen activator remained elevated, resulting in late fibrinolytic activation on postoperative day 3 . In accordance with elevated prothrombin fragment $1+2$, platelet count, antithrombin III, protein $\mathrm{C}$, prothrombin, and factor VII were decreased on postoperative day 2 , indicating ongoing consumptive coagulopathy. Nine patients had antithrombin III and six had protein $\mathrm{C}$ levels below age-specific normal ranges, consistent with an acquired deficiency state. Three had central venous thrombosis by postoperative day 4 or 5 . In all three, thrombosis was preceded by antithrombin Ill deficiency, protein $\mathrm{C}$ deficiency, and highly elevated plasminogen activator inhibitor ( 3.7 to 37 times the mean of the other patients) on postoperative days 1 to 3 . In conclusion, cardiopulmonary bypass in neonates caused rapid and profound alterations in the coagulation and fibrinolytic systems and initiated consumptive coagulopathy lasting until at least postoperative day 3 . Thrombophilic abnormalities in antithrombin $\mathrm{HI}$, protein $\mathrm{C}$, and fibrinolysis were frequently found and were associated with serious thrombotic complications. (J Thorac Cardiovasc Surg 1996;112:665-71)
C rdiopulmonary bypass (CPB) causes multiple alterations in the hemostatic system. These include alterations in platelet function, coagulation factors, fibrinolytic system, and physiologic inhibi-

From the Children's Hospital, University of Helsinki, ${ }^{a}$ and the Finnish Red Cross Blood Transfusion Service, ${ }^{\text {b }}$ Helsinki, Finland.

Received for publication Sept. 28, 1995; revisions requested Dec. 6,1995 ; revisions received Jan. 1, 1996; accepted for publication Jan. 26, 1996.

Address for reprints: Jari Petäjä, MD, Department of Molecular and Experimental Medicine, The Scripps Research Institute, 10666 North Torrey Pines Rd., SBR-5, La Jolla, CA 92037.

Copyright $(\mathbb{C} 1996$ by Mosby-Year Book, Inc.

0022-5223/96 $\$ 5.00+0 \quad \mathbf{1 2 / 1 / 7 2 3 1 7}$ tors of coagulation. ${ }^{1-8}$ As a consequence, perioperative and postoperative bleeding, as well as early thrombotic events, may constitute significant problems. ${ }^{3,9,10}$ These problems are especially frequent in neonates, and the need for blood products is greater in the neonates and young infants than in older children. ${ }^{11,12}$ The hemostatic system of a neonate is immature and different from that of an adult. ${ }^{13,14}$ Therefore information obtained from studies in adults and older children may have limited application to neonates. However, studies of hemostatic effects of CPB in neonates are remarkably few. ${ }^{2,15}$ To elucidate the mechanisms of bleeding and thrombotic complications, we investigated the coagulation and fibrinolytic systems during and after 
CPB and also evaluated the behavior of the two main physiologic anticoagulants, antithrombin III and protein $\mathrm{C}$, in neonates undergoing cardiac operations for congenital heart defects.

\section{Patients and methods}

Patients. The patient series is composed of 10 consecutive term neonates who had cardiac operations at our hospital between October 1994 and February 1995. The ages of the patients varied from 4 to 14 days (mean 8 days). There were seven boys and three girls. The cardiac defects were as follows: transposition of great arteries without additional significant defects $(n=4)$, transposition and ventricular septal defect $(n=3)$, transposition, ventricular septal defect, and aortic coarctation $(n=1)$, aortic valvular stenosis $(n=1)$, and transposition and double-outlet right ventricle $(n=1)$.

Operations and CPB. Standardized surgical and CPB techniques were used, with core cooling down to $15^{\circ}$ to $24^{\circ} \mathrm{C}$. In association with circulatory arrest $(n=3)$, hypothermia varied from $15^{\circ}$ to $18^{\circ} \mathrm{C}$. Cold blood cardioplegia was used for myocardial preservation. Before the aorta was unclamped, a warm cardioplegic solution ("hot shot"; $100 \mathrm{ml}$ Plegisol solution $+100 \mathrm{ml}$ whole blood + $440 \mathrm{mg}$ glutamate $+440 \mathrm{mg}$ aspartate $+20 \mathrm{mg}$ allopurinol $+2 \mathrm{mmol}$ potassium chloride, dose $300 \mathrm{ml} / \mathrm{m}^{2}$, temperature $34^{\circ}$ to $37^{\circ} \mathrm{C}$ ) was administered. The anesthetics consisted of alfentanil and midazolam by infusion and pancuronium for muscular relaxation. Whole blood, donated 20 to 28 hours before the operation (except for operations on Mondays, for which the blood was donated on the previous Saturday), was used to prime the CPB circuit (Lilliput, Sorin-Dideco, Mirandola, Italy). The blood was tested for antibodies against human immunodeficiency and hepatitis $C$ viruses and the presence of surface antigen of hepatitis B virus. Also used as a prime was $4 \%$ human albumin solution. The volume of the CPB circuit is $300 \mathrm{ml}$ with 3/16-inch diameter tubes (patient weight less than $4 \mathrm{~kg}$ ) and $400 \mathrm{ml}$ with $1 / 4$-inch diameter tubes (patient weight at least $4 \mathrm{~kg}$ ). The dilution of the prime was calculated to achieve a hematocrit value of $25 \%$. In the calculation the blood volume of a neonate is estimated to be $85 \mathrm{ml} / \mathrm{kg}$. The weights of the patients varied from 2.84 to $4.5 \mathrm{~kg}$ (mean \pm standard error of the mean [SEM], $3.52 \pm 0.202 \mathrm{~kg}$ ) and the preoperative hematocrit values varied from $46 \%$ to $60 \%$ (mean \pm SEM, $54 \% \pm 1.7 \%$ ). Consequently, in seven patients only $4 \%$ albumin was used for the prime. The whole volume of cardioplegic solution was hemofiltered, and during rewarming the hematocrit value was elevated to the target value by adding whole blood to the $\mathrm{CPB}$ circuit while continuing the hemofiltration. Thus the patients received $525 \pm 96 \mathrm{ml}$ (mean \pm SEM) of whole blood. In five patients red blood cell concentrates were also used after CPB during the operation. Hemostasis during the operation was supported by giving fresh frozen plasma $(n=4)$, platelet concentrates $(n=4)$, and/or cryoprecipitate $(n=$ 4) to six patients. Need for these products during CPB was subjectively evaluated by the surgeon and the anesthesiologist. Eight patients received factor IX concentrate, 500 $(n=7)$ to $1000 \mathrm{IU}(n=1)$, in the prime at the end of CPB.
Aprotinin was given to all patients: first $30,000 \mathrm{IU} / \mathrm{kg} 1$ hour after induction of anesthesia, 30,000 IU/kg into the prime, and $8000 \mathrm{IU} / \mathrm{kg}$ per hour during CPB. Giving factor IX concentrate and aprotinin reflects the current protocol for neonatal CPB at our hospital. Eight patients received amrinone $(2 \mathrm{mg} / \mathrm{kg}$ loading when the aorta was opened, followed by $7.5 \mu \mathrm{g} / \mathrm{kg}$ per minute infusion) during the study period. CPB time varied from 54 to 433 minutes (mean \pm SEM, $174 \pm 31$ minutes). The heparin effect was neutralized by injecting protamine (first $2 \mathrm{mg} / \mathrm{kg}$ and then additional doses according to the activated clotting times). Activated clotting time was measured by means of highrange heparinase cartridges (Medtronic HemoTec, Inc. Englewood, Colo.). The postoperative care in the intensive care unit lasted 3 to 12 days (mean \pm SEM, $6.9 \pm 1.0$ days). During intensive care, major complications occurred in six patients; one of them died, and the other five recovered well. Two patients underwent resternotomy necessitated by bleeding (surgical bleeding in one and nonsurgical bleeding in the other), and one patient had restemotomy and successful cardiopulmonary resuscitation for asystole, probably caused by an episode of pulmonary hypertension. Thrombosis developed in three patients, in the superior vena cava in two and in the innominate vein in one. One of these patients died on postoperative day 4 . The other thrombi were diagnosed in reoperations on postoperative days 4 and 5 .

Postoperative use of blood products. During the first 3 postoperative days all patients received red blood cells (mean $\pm \mathrm{SEM}, 38 \pm 4 \mathrm{ml} / \mathrm{kg}$ ). Additionally, seven patients received fresh frozen plasma $(25 \pm 11 \mathrm{ml} / \mathrm{kg})$ and three received platelet concentrates $(3.7$ to $14.7 \mathrm{ml} / \mathrm{kg}$ ).

Samples and analytic methods. The preoperative screening of coagulation consisted of activated partial thromboplastin time, prothrombin time, and platelet count. In the postoperative period, activated partial thromboplastin time and prothrombin time were measured when clinically indicated. Hemoglobin concentration, hematocrit value, and platelet count were analyzed daily. For coagulation studies, the blood was drawn through indwelling arterial lines. Nine volumes of blood were mixed with 1 volume of $0.129 \mathrm{~mol} / \mathrm{L}$ trisodium citrate. Plasma was immediately separated by centrifugation (1900 $\mathrm{g}$ for 20 minutes) and frozen at $-70^{\circ} \mathrm{C}$ until assayed. For prothrombin fragment $1+2(\mathrm{~F} 1+2), 0.6 \mathrm{ml}$ of blood was collected in heparin (Microtainer, Becton Dickinson \& Co., Rutherford, N.J.), after which plasma was separated by centrifugation and stored at $-70^{\circ} \mathrm{C}$. The samples were collected as follows: after induction of anesthesia before CPB (referred to as "preoperative" sample), during CPB 10 minutes after the aorta was opened, after CPB 15 minutes after injection of protamine, and on postoperative days 1 to 3 .

Factor VII and prothrombin activities were measured with the one-stage method by the use of rabbit brain thromboplastin (Thromboplastin IS, Baxter Healthcare Corporation, Dade International, Inc., Miami, Fla.). The assays were carried out in an ACL $300 \mathrm{R}$ coagulometer (ACL Inc., Elk Grove Village, Ill.). A frozen plasma pool was taken as $100 \%$ activity. Antithrombin III was measured with the ACL $300 \mathrm{R}$ coagulometer with an IL test antithrombin III kit from Instrumentation Laboratory 
Table I. Coagulation parameters in the 10 patients

\begin{tabular}{llccccc}
\hline \multicolumn{1}{c}{ Sample } & $\begin{array}{c}F 1+2 \\
(\mathrm{pmol} / \mathrm{ml})\end{array}$ & $\begin{array}{c}\text { AT III } \\
(\%)\end{array}$ & $\begin{array}{c}P C \\
(\%)\end{array}$ & $\begin{array}{c}\text { FVI } \\
(\%)\end{array}$ & $\begin{array}{c}\text { Prothrombin } \\
(\%)\end{array}$ & $\begin{array}{c}\text { Platelets } \\
\left(10^{\circ} / \mathrm{L}\right)\end{array}$ \\
\hline Preoperative & $1.1 \pm 0.2$ & $44 \pm 4$ & $26 \pm 1$ & $55 \pm 5$ & $55 \pm 4$ & $352 \pm 41$ \\
During CPB & $2.6 \pm 0.3 \dagger$ & $41 \pm 4$ & $36 \pm 5$ & $31 \pm 3 \ddagger$ & $35 \pm 2 \S$ & $71 \pm 14 \ddagger$ \\
During CPB, C & $5.2 \pm 0.7 \S$ & $78 \pm 4 \S$ & $66 \pm 5 \S$ & $63 \pm 8$ & $71 \pm 7^{*}$ & $139 \pm 25 \S$ \\
After CPB & $4.4 \pm 0.7 \S$ & $51 \pm 4$ & $74 \pm 12 \dagger$ & $63 \pm 10$ & $80 \pm 8^{*}$ & $99 \pm 20 \S$ \\
After CPB, C & $6.6 \pm 1.0 \S$ & $77 \pm 5 \S$ & $112 \pm 20 \dagger$ & $94 \pm 13^{*}$ & $123 \pm 14 \dagger$ & $155 \pm 33 \S$ \\
POD 1 & $2.4 \pm 0.6^{*}$ & - & - & - & - & $158 \pm 29 \ddagger$ \\
POD 2 & $1.7 \pm 0.3^{*}$ & $29 \pm 3 \dagger$ & $21 \pm 2 \dagger$ & $23 \pm 4 \S$ & $48 \pm 3$ & $115 \pm 16 \ddagger$ \\
POD 3 & $3.0 \pm 0.5 \dagger$ & - & - & - & - & $104 \pm 22 \ddagger$ \\
\hline
\end{tabular}

$F 1+2$, Prothrombin fragment; $A T I I$, antithrombin III; $P C$, protein C; FVII, factor VII; $\%$, percentage of normal adult mean; $C$, values corrected for hematocrit change; $P O D$, postoperative day. Values are presented as mean $\pm \mathrm{SEM}$.

${ }^{*} p<0.05$ compared with preoperative value.

$\dagger p<0.01$ compared with preoperative value.

$\ddagger p<0.001$ compared with preoperative value.

$\S p<0.0001$ compared with preoperative value.

S.P.A., Milan, Italy. IL calibration plasma was used as a standard. Protein $\mathrm{C}$ was measured by means of a chromogenic method with S-2366 (Chromogenix AB, Mölndal, Sweden) used as a substrate and protein $\mathrm{C}$ activator (American Diagnostica, Inc., Greenwich, Conn.). Again, a frozen plasma pool was taken as $100 \%$ activity. D-dimer was assayed with an enzyme-linked immunosorbent assay method using Asserachrom D-Di from Diagnostica-Stago, Asnieres, France, as described by the manufacturer. Plasminogen activator inhibitor (PAI) and tissue plasminogen activator ( $t-P A)$ were measured with Coatest PAI and Coatest t-PA, respectively (Chromogenix AB). F1+2 was measured with Thrombonostika F1.2 from Organon Teknika Corp., Durham, North Carolina, as described by the manufacturer.

D-dimer levels were highly increased on postoperative day 3. Four patients had values above $4000 \mathrm{ng} / \mathrm{ml}$, one above $3000 \mathrm{ng} / \mathrm{ml}$, and two above $2000 \mathrm{ng} / \mathrm{ml}$. Inasmuch as there was not enough plasma to titrate these levels further, these minimum estimates were used in subsequent analysis.

In the following text, "normal ranges" refer to the values for term healthy neonates at the age of 5 days reported by Andrew, Paes, and Johnston. ${ }^{13}$

Correction for hemodilution. During CPB, the blood is diluted by the $4 \%$ albumin solution in the prime and by intravenous fluids. This addition of water masks the effects of plasma protein substitution, production or release in the body, and their consumption. To uncover the net effect of these mechanisms, the results from samples taken during operation were corrected for hemodilution by a correction factor, $\mathrm{F}$, calculated by the following formula ${ }^{16}$ :

$$
\mathrm{F}=\frac{\left(100-\mathrm{Hct}_{\mathrm{sample}}\right) \cdot \mathrm{Hct}_{\mathrm{preCPB}}}{\left(100-\mathrm{Hct}_{\mathrm{preCPB}}\right) \cdot \mathrm{Hct}_{\text {sample }}}
$$

where Hct is hematocrit.

Statistical methods. The two-tailed Student's $t$ test for paired samples or the Wilcoxon signed rank test was used for comparisons, and $p<0.05$ was regarded as significant.
The study protocol was approved by the ethics committee of the Children's Hospital, University Central Hospital of Helsinki. Informed consent was obtained from the parents of each patient before entry into the study.

\section{Results}

Activation of coagulation. Net activation of coagulation was measured as $\mathrm{F} 1+2$, which reflects prothrombin activation to thrombin. Behavior of F1+2 is shown in Table I. F1+2 increased substantially during $\mathrm{CPB}$. The levels of $\mathrm{F} 1+2$ remained elevated during postoperative days 1,2 , and 3. Factor VII and prothrombin were decreased on postoperative day 2 (Table I). Platelet count decreased progressively until postoperative day 3 (Table I).

Fibrinolysis. Results of fibrinolytic studies (t-PA, PAI, and D-dimer) are shown in Fig. 1. Both t-PA and PAI levels increased rapidly during $\mathrm{CPB}$. The response of PAI peaked after the aorta was opened during $\mathrm{CPB}$, whereas peak t-PA values were seen after the administration of protamine. The PAI level had already returned to normal on postoperative day 1 , whereas t-PA levels remained significantly elevated on postoperative day 3 . In accordance with an extensive but transient increase in PAI and a sustained t-PA increase, the D-dimer level remained relatively stable until postoperative day 1 but then sharply increased by postoperative day 3. In two patients, additional PAI and t-PA values were obtained from samples starting 30 minutes before the "during CPB" sample and continuing on 30-minute intervals until the "after CPB" sample. In both patients the highest PAI values were seen in the first sample, whereas t-PA peaked in the "after CPB" 

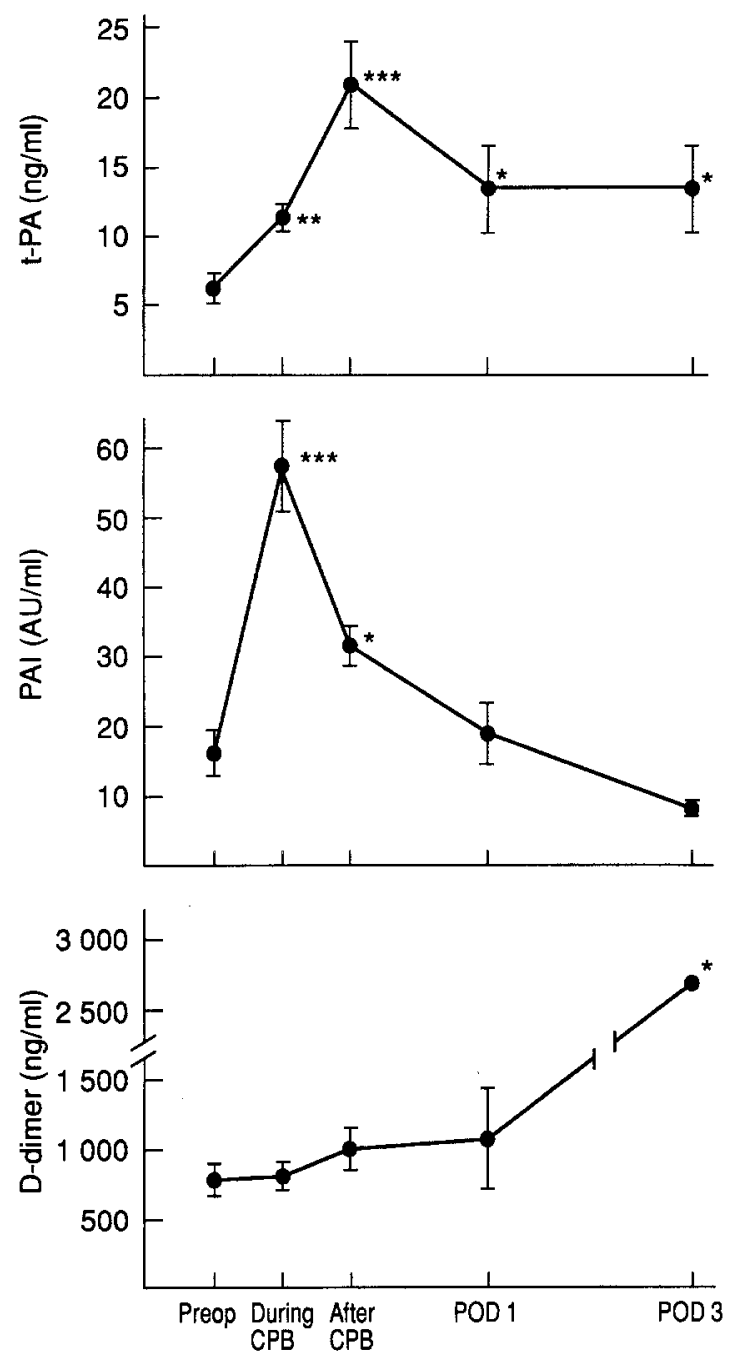

Fig. 1. Fibrinolytic studies in the 10 patients. Values are presented as mean \pm SEM. PAI values represent those of seven patients who were free of thrombosis. Exact Ddimer levels on postoperative day 3 were unknown but were above $2000 \mathrm{ng} / \mathrm{ml}$ or $4000 \mathrm{ng} / \mathrm{ml}$ in seven patients. In statistical evaluation, these cutoff points were used and significance was calculated by the Wilcoxon signed rank test. ${ }^{*} p \leq 0.05, * * p \leq 0.01, * * * p \leq 0.001$ compared with preoperative values. $P O D$, Postoperative day.

sample or in the sample preceding it (data not shown). Thus the PAI response would probably have been even faster and more pronounced if sampling intervals had been smaller.

Antithrombin III and protein C. Levels of antithrombin III and protein C are shown in Table I. Antithrombin III was below the reference range ( $41 \%$ to $93 \%$ ) in five of the 10 patients $(50 \%)$ at the beginning of the operation and was low in nine patients on postoperative day $2(90 \%)$ (Fig. 2). Protein $\mathrm{C}$ was within normal limits $(20 \%$ to $64 \%)$ in every patient at the beginning of the operation but low in six patients $(60 \%)$ on postoperative day 2 (Fig. 2).

Patients with thrombosis. Individual postoperative levels of antithrombin III, protein C, and PAI are shown in Fig. 2. The three patients in whom thrombosis developed by postoperative day 4 or 5 had low antithrombin Ill and protein $C$ levels on postoperative day 2 . The behavior of PAI was highly abnormal. PAI values on postoperative day 1 varied from 70 to $700 \mathrm{AU} / \mathrm{ml}$ in the patients having thrombosis, whereas the highest PAI value in thrombosisfree patients was $43 \mathrm{AU} / \mathrm{ml}$. This disparity was clear also on postoperative day 3. Except for PAI, the pattern of changes in studied parameters (including F1+2) did not differ between patients with and without thrombosis. The abnormal behavior of PAI in the patients with thrombosis was seen only in the postoperative period. During and before $\mathrm{CPB}, \mathrm{PAI}$ values in these three patients were within the range of the rest of the patients.

\section{Discussion}

This is the first study to demonstrate a rapid t-PA release counteracted by an even faster rise in PAI during neonatal $\mathrm{CPB}$. PAI normalized rapidly in patients who were free of thrombosis, whereas t-PA remained elevated. Thus, despite t-PA release, endogenous fibrinolysis was inhibited during the operation. Moreover, after normalization of PAI, fibrinolysis was activated in the late postoperative period (postoperative day 3), as evidenced by the highly elevated levels of fibrin degradation product $\mathrm{D}$ dimer.

We believe that these observations of t-PA and PAI changes are not affected by the use of aprotinin. Aprotinin inhibits serine proteases including plas$\mathrm{min}$, but there is no evidence that aprotinin would affect the release of either t-PA or PAI from endothelium.

We are familiar with only one relevant study of fibrinolysis in neonates, where increase in t-PA and fibrin degradation products during neonatal extracorporeal life support was observed only after 48 hours. ${ }^{15}$ However, the sampling intervals in that study were such that early and transient changes in fibrinolysis could easily have been missed.

Surgical stress causes intraoperative t-PA release, ${ }^{17}$ and this has been seen also during CPB. ${ }^{18,19}$ 


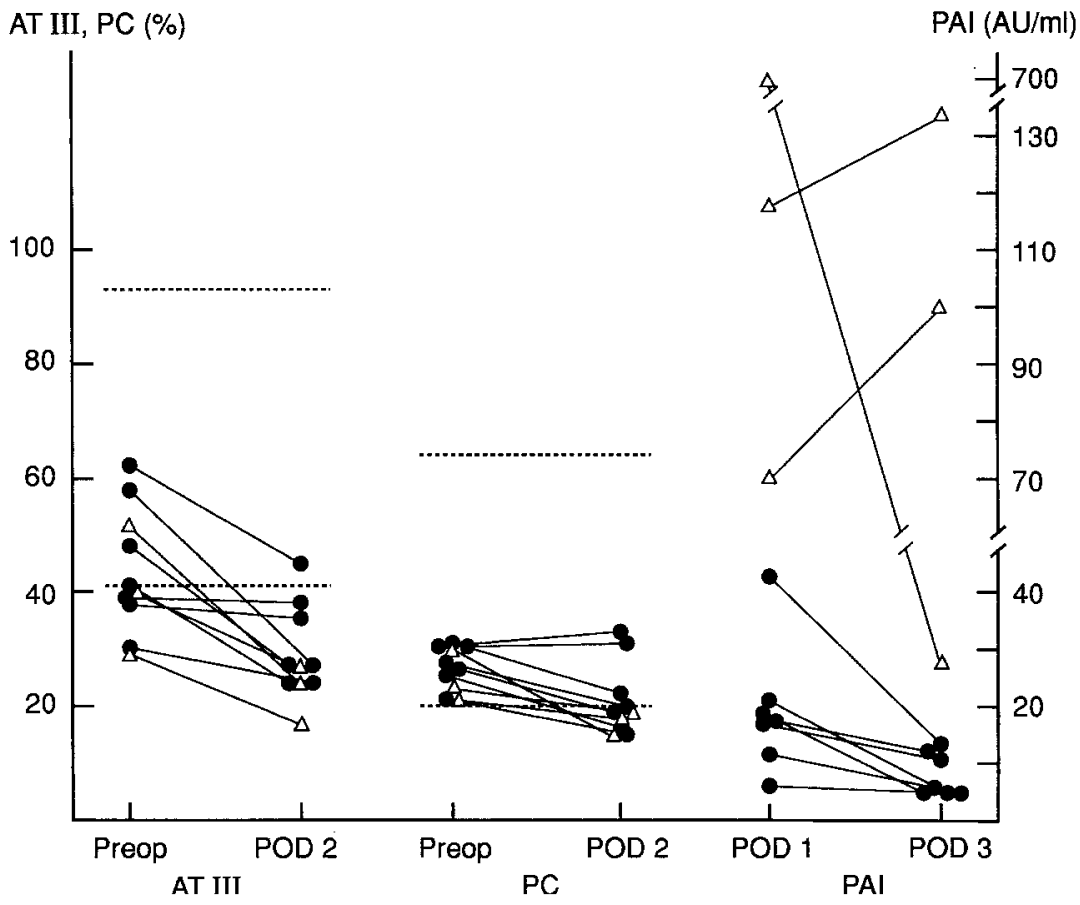

Fig. 2. Individual values of antithrombin III (AT III), protein $\mathrm{C}(P C)$, and PAI. The dotted lines refer to reported normal ranges for antithrombin III and protein $\mathrm{C}^{16}$ Open triangles refer to patients with thrombosis.

However, net activation of fibrinolysis during CPB is rarely seen, ${ }^{6}$ as was the case also in our study. In addition to the observed physiologic fibrinolytic shutdown, fibrinolysis was further inhibited by aprotinin, which inhibits plasmin action. It is not possible to quantitate the relative contribution of these two simultaneous inhibitory mechanisms to net fibrinolysis. However, it can be concluded that inasmuch as fibrinolysis was inhibited both physiologically and pharmacologically during $\mathrm{CPB}$, hyperfibrinolysis was probably not a cause of bleeding during the operations. Thus additional antifibrinolytic drugs may be of little value during CPB in neonates, although this theory needs to be tested in future studies. Unlike during the operation, fibrinolysis was activated after the operation. Because of sustained t-PA release, hyperfibrinolysis may contribute to late postoperative bleeding complications.

$\mathrm{CPB}$ activates coagulation. The indicators of thrombin formation and/or action like $\mathrm{F} 1+2$, fibrinopeptide A, soluble fibrin monomer, and antithrombin III-thrombin complexes are elevated at the end of CPB. ${ }^{1,15,20}$ This was clearly seen also in the present study. However, it is not as clear for how long and how often this activation continues during intensive care. Obviously, individual patients and patient populations differ from each other. Many factors especially prominent in neonates, for example, hemodynamic lability resulting in tissue hypoperfusion, hepatic immaturity, and infections, may trigger or maintain disseminated intravascular coagulation. One of our patients had a resternotomy because of diffuse bleeding on the day of the operation. Otherwise we observed no overt postoperative bleeding. $\mathrm{F} 1+2$ was elevated in every postoperative sample and even rose from postoperative day 2 to postoperative day 3. Levels of antithrombin III, protein C, prothrombin, and factor VII were decreased. Progressive thrombocytopenia, increased t-PA release, and high levels of fibrin degradation products were also present.

Our findings of activated coagulation and fibrinolysis associated with decrease in several coagulation factors are consistent with subclinical disseminated intravascular coagulation until at least postoperative day 3 . We believe that this subclinical consumptive coagulopathy may be important for two reasons. First, in addition to the bleeding risk in the area of 
the operation, sick neonates are at risk for intracranial hemorrhage. ${ }^{23}$ Second, there is a risk of thrombosis.

Eight patients received factor IX concentrate at the end of $\mathrm{CPB}$, which might have influenced the measured hemostatic variables. However, we could not observe such an effect because the patterns of coagulation and fibrinolysis changes in the two patients who did not receive factor IX concentrate were essentially the same as in the rest of the patients. For example, the two patients without factor IX concentrate had 7.2-fold and 4.2-fold increases in F1+2 level at the end of the operation and on postoperative day 3 , respectively, compared with the preoperative levels (data not shown). Eight patients received amrinone, which may have influenced the degree of thrombocytopenia. ${ }^{21,22}$

Antithrombin III and protein C are central physiologic anticoagulants. Deficiencies of antithrombin III and protein $\mathrm{C}$ may cause thrombosis during the neonatal period. ${ }^{24,25}$ Data concerning effects of neonatal CPB on anticoagulant levels is sparse and inconsistent. Kern and associates ${ }^{2}$ found higher levels of antithrombin III in the postoperative period compared with the preoperative values but did not indicate how many patients had values below the normal range for age. Boldt and coworkers ${ }^{1}$ found that antithrombin III decreased from a mean preoperative value of $77 \%$ to $58 \%$ in neonates and small infants but provided no data on individual levels. They also found low postoperative concentrations of protein $\mathrm{C}$.

In the present study, the pattern of antithrombin III and protein $\mathrm{C}$ changes was very constant from patient to patient. The administered blood and blood products maintained the concentrations of these proteins almost invariably in the normal range during CPB despite hemodilution. Actually, the values corrected for hemodilution showed that the absolute amounts of antithrombin III and protein $\mathrm{C}$ in the circulation were, respectively, 1.8 and 4.3 times the amounts measured in the preoperative period. Despite this iatrogenic increase, both antithrombin III and protein C decreased in the postoperative period. The mechanism was most likely consumption. Individual postoperative values were consistent with the deficiency state in $90 \%$ and $60 \%$ of the patients for antithrombin III and protein $\mathrm{C}$, respectively. Antithrombin III deficiency was already present preoperatively in $50 \%$ of the patients. In conclusion, a majority of the patients had at least two thrombophilic coagulation abnormalities.

Central venous thrombosis developed for up to 5 days after the operation in three patients-fatal in one and nonfatal in the other two. Inasmuch as the diagnosis of thrombosis was clinical, occurrence of additional subclinical thrombi cannot be excluded. This high rate of thrombosis seems coincidental, because the patient care was unaltered from our routine care, and during the past 10 years our incidence of clinical thrombosis has been $5.8 \%$ in neonates and $0.6 \%$ in older children after $\mathrm{CPB}$.

Thrombogenesis has a multifactorial background and is probably most often triggered by central venous catheters. ${ }^{10,26}$ Every patient in our series had a central venous line and the catheters probably were the most important factors in the development of thrombosis. However, we believe that the complicated coagulopathy contributed to thrombogenesis as well. Antithrombin III and protein C deficiencies were present in all three patients before thrombosis. The most striking finding was extremely high values of PAI both in absolute terms and in comparison with the values in patients who were thrombosis-free. Actually, the PAI value of 700 $\mathrm{AU} / \mathrm{ml}$ is the highest value ever measured in our coagulation laboratory. The PAI probably originated from the endothelium, because platelet-derived PAI is inactive in t-PA activity-based assays. ${ }^{27}$ This high release of PAI seemed to be a specific postoperatively acquired fibrinolytic disorder of the endothelium, since postoperative t-PA values and preoperative PAI values in the patients with thrombosis were similar to those of the patients not having thrombosis. We conclude that high levels of PAI during the days when thrombi were developing most likely contributed to the thrombogenesis in the three patients. Further, PAI measurement on postoperative days 1 and 3 elegantly predicted which patients would have thrombosis. However, this predictive property of PAI measurement needs to be reproduced in a larger prospective study with detection also of subclinical thrombi.

To summarize, neonatal CPB was associated with sustained consumptive coagulopathy and activated fibrinolysis during the immediate postoperative phase. This resulted in deficiencies of both antithrombin III and protein $\mathrm{C}$ in the majority of patients. These deficiencies, in association with abnormal inhibition of fibrinolysis, were associated with severe thrombotic complications. Future studies of neonates are needed to minimize the trauma 
to blood caused by CPB and to assess the value of different therapeutic approaches to the coagulopathy. Specifically, serial measurements of antithrombin III, protein C, and PAI and replacement therapy for observed deficiencies may be indicated in this patient group at high risk of postoperative thrombosis.

\section{REFERENCES}

1. Boldt J, Knothe C, Schindler E, Welters A, Dapper F, Hempelmann G. Thrombomodulin in pediatric cardiac surgery. Ann Thorac Surg 1994;57:1584-9.

2. Kern FH, Morana NJ, Sears JJ, Hickey PR. Coagulation defects in neonates during cardiopulmonary bypass. Ann Thorac Surg 1992;54:541-6.

3. Woodman RC, Harker LA. Bleeding complications associated with cardiopulmonary bypass. Blood 1990;76:1680-97.

4. Harker LA, Malpass TW, Branson HE, Hessel EA, Slichter SJ. Mechanism of abnormal bleeding in patients undergoing cardiopulmonary bypass: acquired transient platelet dysfunction associated with selective alfa-granule release. Blood 1980;56:824-34.

5. Turner-Gomes SO, Andrew M, Coles J, Trusler GA, Williams WG, Rabinovitch M. Abnormalities in von Willebrand factor and antithrombln III after cardiopulmonary bypass operations for congenital heart disease. $\mathbf{J}$ Thorac Cardiovasc Surg 1992;103:87-97.

6. Mammen EF, Koets MH, Washington BC, Wolk LW, Brown JM, Burdick M, et al. Hemostasis changes during cardiopulmonary bypass surgery. Semin Thromb Hemost 1985;11: 291-2.

7. Gill JC, Wilson AD, Endres-Brooks J, Montgomery RR. Loss of the largest von Willebrand factor multimers from the plasma of patients with congenital cardiac defects. Blood 1986;67:758-61.

8. Kestin AS, Valeri R, Khuri SF, Loscalzo J, Ellis PA, MacGregor $\mathrm{H}$, et al. The platelet function defect of cardiopulmonary bypass. Blood 1993;82:107-17.

9. Cosgrove DM, Loop FD, Lytle BW, Gill CC, Golding LR, Taylor PC, et al. Determinants of blood utilization during myocardial revascularization. Ann Thorac Surg 1985;40: 380-4.

10. Moore RA, McNicholas KW, Naidech H, Flicker S, Gallagher JD. Clinically silent venous thrombosis following internal and external jugular central venous cannulation in pediatric cardiac patients. Anesthesiology 1985;19:536-8.

11. Petäjä J, Lundström U, Leijala $M$, Peltola K, Siimes MA. Bleeding and use of blood products after heart operations in infants. J Thorac Cardiovasc Surg 1995;109:524-9.
12. Manno CS, Hedberg KW, Kim HC, Bunin GR, Nicolson S, Jobes D, et al. Comparison of the hemostatic effects of fresh whole blood, stored whole blood and components after open heart surgery in children. Blood 1991;77:930-6.

13. Andrew M, Paes B, Johnston M. Development of the hemostatic system in the neonate and young infant. Am J Pediatr Hematol Oncol 1990;12:95-104.

14. Jobes DR, Nicolson SC, Steven JM. Inhibition and restoration of hemostasis in the young cardiac surgical patient. Cardiol Young 1993;3:370-7.

15. Ploz FB, Oeveren W, Bartlett RH, Wildevuur CR. Blood activation during neonatal extracorporeal life support. J Thorac Cardiovase Surg 1993;105:823-32.

16. Van Beaumont W. Evaluation of hemoconcentration from hematocrit measurements. J Appl Physiol 1972;32:712-3.

17. Mellbring G, Dahlgren S, Wiman B. Plasma fibrinolytic activity in patients undergoing major abdominal surgery. Acta Chir Scand 1985:151:109-14.

18. Stibbe J, Kluft C, Brommer EJP, Gomes M, DeJong DS, Nauta J. Enhanced fibrinolytic activity during cardiopulmonary bypass in open heart surgery in man is caused by extrinsic (tissue-type) plasminogen activator. Eur $\mathbf{J}$ Clin Invest 1984;14:375-82.

19. deProst D, Barbier-Boehm G, Hazebroucq J, Ibrahim H, Bielsky MC, Hvass U, et al. Desmopressin has no beneficial effect on excessive postoperative bleeding or blood product requirements associated with cardiopulmonary bypass. Thromb Haemost 1992;68:106-10.

20. Slaughter TF, LeBleu TH, Douglas JM, Leslie JB, Parker JK, Greenberg CS. Characterization of prothrombin activation during cardiac surgery by hemostatic molecular markers. Anesthesiology 1994;80:520-6.

21. Levy JH, Bailey JM. Amrinone: pharmacokinetics and pharmacodynamics. J Cardiothoracic Anesth 1989;3(Suppl):10-4.

22. Notterman DA. Inotropic agents: catecholamines, digoxin, amrinone. Crit Care Clin 1991;7:583-613.

23. McDonald MM, Johnson ML, Rumack CM, Koop BL, Guggenheim MA, Babb C, et al. Role of coagulopathy in newborn intracranial hemorrhage. Pediatrics 1984;74:26-31.

24. Manco-Johnson MJ. Neonatal antithrombin III deficiency. Am J Med 1989;87:49-52.

25. Manco-Johnson MJ, Abshire TC, Jacobson LJ, Marlar RA. Severe neonatal protein $\mathrm{C}$ deficiency: prevalence and thrombotic risk. J Pediatr 1991;119:793-8.

26. David M, Andrew M. Venous thromboembolic complications in children. J Pediatr 1993;123:337-46.

27. Erikson E, Ranby M, Gyzander E, Risberg B. Determination of plasminogen activator inhibitor in plasman using t-PA and a chromogenic single-point poly-D-lysine stimulated assay. Thromb Res 1988;50:91-101. 